AGRICULTURE AND BIOLOGY JOURNAL OF NORTH AMERICA

ISSN Print: 2151-7517, ISSN Online: 2151-7525, doi:10.5251/abjna.2011.2.10.1347.1350

(C) 2011, ScienceHu $\beta$, http://www.scihub.org/ABJNA

\title{
Performance and carcass characteristics of broilers raised on three different litter materials
}

\author{
Onu P.N. ${ }^{1}$, Madubuike, F.N. ${ }^{2}$, Nwakpu P.E ${ }^{1}$ Anyaehie, A.I. ${ }^{2}$ \\ ${ }^{1}$ Department of Animal Production and Fisheries Management, Ebonyi State University \\ P.M.B. 053, Abakaliki, Ebonyi State. E- mail: nnenwamazi@yahoo.com \\ ${ }^{2}$ Department of Animal Science, Imo State University, P.M.B. 2000, Owerri, Imo State.
}

\begin{abstract}
Two experiments were conducted to determine the impact of three litter materials (saw dust, wood shavings and rice husks) on the performance and carcass characteristics of broilers chicks. In the first or second trial, a total of 120 one-day-old or 96 five-week-old broiler chicks were randomly allotted to three groups, each of which included four replicates (10 or 8 chicks per replicate). In both trials, each group was reared on three litter materials, respectively, and received the same starter (the $1^{\text {st }}$ trial) and finisher (the $2^{\text {nd }}$ trial) diet for 35 days. Body weight gain (BWG), feed intake (FI), feed conversion ratio (FCR) and survivability during the experimental period were measured as performance parameters. At the end of the $2^{\text {nd }}$ trial, three birds were randomly selected from each replicate group and slaughtered for carcass evaluation. In the $1^{\text {st }}$ trial, $\mathrm{Fl}$ of birds reared on rice husks was significantly $(\mathrm{P}<0.05)$ lower feed than those reared on the other litter materials. The decrease of $\mathrm{Fl}$ on rice husks may be due the scavenged broken rice particles from the litter. BWG, FCR and survivability were not affected by the type of litter material. In the $2^{\text {nd }}$ trial, FCR of the birds on rice husks was significantly $(P<0.05)$ improved compared with those on the other litter materials. FI, BWG and survivability were not affected by the type of litter materials. Also, the weight of carcass or organ was not affected by the type of litter materials. In conclusion, rice husks proved to be slightly better as litter material for broiler rearing among the available litter materials in Nigeria.
\end{abstract}

\section{Keywords: broiler chicks, litter materials, performance, carcass characteristics} \section{INTRODUCTION}

The poultry industry has in recent years occupied a leading position among agricultural industries in many parts of the world. Poultry meat and eggs serve as important sources of high quality animal protein in those areas of the world that have protein insufficiency. In the past decade, the poultry industry has undergone very rapid development and it is expected that this development will be more pronounced in developing countries than in developed regions of the world Daghir, ${ }^{[4]}$. This is because most developed countries have already reached self-sufficiency, while developing countries have not.

Intensive poultry production was introduced into Nigeria over fifty years ago and has developed rapidly especially in the last few decades as an important livestock enterprise in the country FAO, ${ }^{[6]}$. The rapid expansion of the poultry industry is due to the attractive attributes of poultry. These attributes include the ability to adapt easily, high economic value, rapid generation time and a high rate of growth that can result in the production of meat within 8 weeks and first egg within eighteen weeks of the first chick being hatched Smyth, ${ }^{[13]}$.

Of all poultry production technologies, non has received attention and interest of animal scientists as nutrition especially the utilization of non-conventional feed (NCF) sources for the feeding of poultry Babatunde, [3]. However with the increasing concentration of poultry in Nigeria has come the need to better appreciate the influence of litter materials on which these birds are raised on the performance of the animals.

In Nigeria, broilers and cockerels are mostly reared on the floor spread with litter materials. Litter material is any dry material used on the floor of chicken houses on which chicken dropping will fall. It is known as litter material because it combines with the droppings and undergoes a bacterial breakdown process, thus preventing a smelly and unsanitary condition Demirulus ${ }^{[5]}$. In Southeastern Nigeria, wood shavings are easily obtained from sawmills at little or no cost and used as litter. The use of this 
Agric. Biol. J. N. Am., 2011, 2(10): 1347-1350

material has been hinged purely on their availability and price, without any consideration for the comfort of the birds.

Few available reports on the effect of litter on the performance of birds are contradictory and showed a need for validation. According to Oliveira et al. ${ }^{[8]}$ ), Awojobi et al. ${ }^{[2],}$ types of litter had no significant effect on birds' performance. Whereas Popolizio et al. [9], Poyraz et al. [10] and Anisuzzaman and Chowdhurry ${ }^{[1]}$ reported that rice husk was the best litter for broiler chickens. Based on these premise, it becomes imperative to evaluate wood shaving and other locally available litter materials in Nigeria such as saw dust and rice husks. This study was therefore designed to evaluate the performance and carcass characteristics of broilers raised on three different litter materials.

\section{MATERIALS AND METHODS}

The experiments were carried out at the Poultry Unit of the Teaching and Research Farm, Ebonyi State University, Abakaliki, Nigeria with the approval of the Committee for Animal Experiments of the Institution.

Wood shavings, saw dust and rice husks were the litter materials used in this study. Saw dust and wood shavings were collected from sawmills, while rice husks was collected from rice mill all in Abakaliki, Ebonyi State, Nigeria. The litter materials were sundried for two days after collection from their sources and used as collected. Each material was spread on the floor to a depth of $5 \mathrm{~cm}$.

At the starter phase (Trial 1), one hundred and twenty Anak 2000 newly hatched broiler chicks were randomly assigned to the three litter materials, giving 40 birds per litter in a completely randomized design (CRD). Each group was further sub-divided into four replicates of 10 birds each and kept in a compartment measuring $3 \times 3 \mathrm{~m}^{2}$. The birds were fed a formulated broiler starter diet (Table 1) ad-libitum throughout the experimental period.

At the finisher phase (Trial 2), a total of ninety-six 5week-old broiler chicks were divided into three groups of 32 birds each and randomly allotted to the three litter materials in a CRD. Each group was further sub-divided into four replicates of eight birds and each replicate was kept in a compartment measuring $4 \times 4 \mathrm{~m}^{2}$. The birds were fed a formulated broiler finisher diet (Table 1) ad-libitum.

In the $1^{\text {st }}$ or $2^{\text {nd }}$ trial, water was supplied liberally throughout the experimental period. Prior to the commencement of the each experiment, the birds were weighed to obtain their initial body weight and thereafter on weekly basis. Feed intake was recorded daily. Other routine poultry management and vaccination procedures were maintained. Each trial lasted 35 days.

Table 1. Composition of the experimental broiler starter and broiler finisher diets

\begin{tabular}{|l|c|c|}
\hline Ingredients & Starter & Finisher \\
\hline Maize & 50.0 & 53.0 \\
\hline Soyabean meal & 15.0 & 15.0 \\
\hline Groundnut cake & 12.0 & 8.0 \\
\hline Fish meal & 6.0 & 5.0 \\
\hline Palm kernel cake & 5.0 & 5.0 \\
\hline Brewers dried grain & 8.0 & 10.0 \\
\hline Bone meal & 2.0 & 2.0 \\
\hline Oyster shell & 1.0 & 1.0 \\
\hline Premix & 0.25 & 0.25 \\
\hline Salt & 0.25 & 0.25 \\
\hline Lysine & 0.25 & 0.25 \\
\hline Methionine & 0.25 & 0.25 \\
\hline Total & 100 & 100 \\
\hline $\begin{array}{l}\text { Chemical composition } \\
\text { of the diets }\end{array}$ & & \\
\hline Nutrients & & \\
\hline Crude Protein & 23.52 & 20.18 \\
\hline Ether Extract & 5.30 & 5.42 \\
\hline Crude Fibre & 4.30 & 4.56 \\
\hline Ash & 4.17 & 3.72 \\
\hline $\begin{array}{l}\text { Metabolizable } \\
\text { 2828.60 2947.56 }\end{array}$ & & \\
\hline Toprovide & & \\
\hline
\end{tabular}

To provide the following per $\mathrm{kg}$ of feed: Vit. A, 10, $000 \mathrm{IU}$, vit $\mathrm{B}_{1}$, $075 \mathrm{~g}$, Biotin, $0.05 \mathrm{~g}$, Folic acid $1 \mathrm{~g}$, Chlorine chloride $250 \mathrm{~g}$ Copper, $8 \mathrm{~g}$, Manganese, $64 \mathrm{~g}$, Iron $32 \mathrm{~g}$, Zn 40g lodine $0.6 \mathrm{~g}$, Flavomycin $100 \mathrm{~g}$, Spiramycin $5 \mathrm{~g}, 3$-nitre $50 \mathrm{~g}$, DL-methionone, $50 \mathrm{~g}$, Selenium, $0.6 \mathrm{~g}$, Lysine $120 \mathrm{~g}$, butylated hydroxy toluene, $5 \mathrm{~g}$.

At the end of the second feeding trial, three birds per replicate were randomly selected, deprived of food but not water for a day. They were then slaughtered and eviscerated for carcass evaluation.

The data collected were subjected to a one-way analysis of variance (ANOVA) for a CRD as outlined by Steel and Torrie ${ }^{[14]}$, while significant variations between treatment means were separated using Duncan's Multiple Range Test as outlined by Obi ${ }^{[7]}$.

\section{RESULTS AND DISCUSSION}

Data on the performance of young and finisher broiler chicks reared on the three litter materials are shown in Tables 2 and 3 respectively. The carcass traits and internal organ weights of the broiler chickens as influenced by the litter materials are shown in Table . 
Table 2. Performance of broiler starters as influenced by the different litter materials

\begin{tabular}{|l|c|c|c|}
\hline Parameters & $\mathbf{T}_{\mathbf{1}}$ & $\mathbf{T}_{\mathbf{2}}$ & $\mathbf{T}_{\mathbf{3}}$ \\
\hline Average daily weight gain (g) & $16.58 \pm 0.15$ & $16.54 \pm 0.17$ & $16.76 \pm 0.14$ \\
\hline Average daily feed intake (g) & $59.03 \pm 0.22^{\mathrm{a}}$ & $59.23 \pm 0.28^{\mathrm{a}}$ & $58.30 \pm 0.30^{\mathrm{D}}$ \\
\hline Feed conversion ratio & $3.56 \pm 0.08$ & $3.58 \pm 0.10$ & $3.48 \pm 0.07$ \\
\hline Survivability (\%) & $98.33 \pm 0.19$ & $99.17 \pm 0.22$ & $97.50 \pm 0.18$ \\
\hline
\end{tabular}

$\mathrm{T}_{1}$ = wood shaving, $\mathrm{T}_{2}$ saw dust, $\mathrm{T}_{\text {= }}$ rice husk, a,b: means within rows with different superscripts are significantly different $\quad(\mathrm{P}<0.05)$.

Table 3. Performance of finisher broilers reared on the three litter materials.

\begin{tabular}{|l|c|c|c|}
\hline Parameters & $\mathbf{T}_{\mathbf{1}}$ & $\mathbf{T}_{\mathbf{2}}$ & $\mathbf{T}_{\mathbf{3}}$ \\
\hline Average daily weight gain $(\mathrm{g})$ & $47.00 \pm 0.24$ & $46.97 \pm 0.22$ & $47.21 \pm 0.10$ \\
\hline Average daily feed intake $(\mathrm{g})$ & $151.52 \pm 0.48$ & $152.18+3.02$ & $145.41+2.99$ \\
\hline Feed conversion ratio & $3.22 \pm 0.09^{\mathrm{b}}$ & $3.24 \pm 0.09^{\mathrm{b}}$ & $3.08 \pm 0.04^{\mathrm{a}}$ \\
\hline Survivability (\%) & 100 & 100 & 100 \\
\hline
\end{tabular}

$\mathrm{T}_{1}$ = wood shaving, $\mathrm{T}_{2}$ saw dust, $\mathrm{T}_{\text {= }}$ rice husk, a,b: means within rows with different superscripts are significantly different $\quad(P<0.05)$.

Table 4. Carcass Characteristics of broilers as influence by the different litter materials.

\begin{tabular}{|l|c|c|c|}
\hline Parameters & $\mathbf{T}_{1}$ & $\mathbf{T}_{2}$ & $\mathbf{T}_{3}$ \\
\hline Dressed weight (kg) & $2.000 \pm 0.04$ & $2.003 \pm 0.03$ & $2.025 \pm 0.05$ \\
\hline Dressing (\%) & $88.58 \pm 0.24$ & $88.41 \pm 0.22$ & $89.03 \pm 3.0$ \\
\hline Neck (\%) & $6.54 \pm 0.13$ & $6.65 \pm 0.14$ & $6.59 \pm 0.06$ \\
\hline Breast (\%) & $20.49 \pm 0.16$ & $20.78 \pm 0.22$ & $21.08 \pm 0.17$ \\
\hline Shanks (\%) & $8.26 \pm 0.12$ & $8.08 \pm 0.12$ & $7.95 \pm 0.10$ \\
\hline Thigh (\%) & $15.68 \pm 0.14$ & $15.48 \pm 0.11$ & $15.75 \pm 0.15$ \\
\hline Organ weights (\% body weight) & $2.30 \pm 0.13$ & $2.25 \pm 0.09$ & $2.20 \pm 0.74$ \\
\hline Liver (\%) & $1.17 \pm 0.14$ & $1.2 \pm 0.08$ & $1.09 \pm 0.11$ \\
\hline Heart (\%) & $2.94 \pm 0.11$ & $2.93 \pm 0.11$ & $2.92 \pm 0.1$ \\
\hline Gizzard (\%) &
\end{tabular}

Means in the same row are not statistically different $(P>0.05), T_{1}=$ wood shaving, $T_{2}=$ saw dust, T3= rice husk

There were significant differences $(P<0.05)$ on the feed intake (FI) of the young broiler chicks (Trial 1). Birds on rice husks litter consumed significantly lower feed than those reared on the other litter materials. However, the FI of the broiler finishers (Trial 2) reared on the three litter materials did not differ significantly $(P>0.05)$.

The higher $\mathrm{FI}$ of the young birds on saw dust and wood shavings could be associated with the fact that the birds could not get much to pick from the litters. It was discovered in the course of the experiment that rice husks used contained some pieces of broken rice. Since birds on rice husks could scavenge on rice husks its FI was reduced. These findings further strengthened the reports of Sharma ${ }^{[12]}$, Anisuzzaman and Chowdhury ${ }^{[1]}$ and Awojobi et al. ${ }^{[2]}$.

The body weight gain (BWG) of the broilers was not affected by the litter materials $(P>0.05)$ in both trials 1 and 2. At the starter phase, birds on rice husks that had the least feed intake recorded comparable $(P>$ 0.05) BWG with those on wood shavings and saw dust. Awojobi et al. ${ }^{[2]}$ had earlier reported similar findings and they attributed this to the presence of some unidentified growth promoting substances in rice husk. The comparable $(P>0.05) B W G$ despite the significant $(P<0.05)$ lower feed intake of bird on rice husks litter could also be attributed to the extra energy supplied by the pieces of broken rice picked from the litter by the birds reared on them.

The feed conversion ratio (FCR) of young broiler chicks reared on the three litter materials did not differ significantly $(P>0.05)$. However, at the finisher stage, birds on rice husk recorded significantly $(P<0.05)$ the best FCR. The poor FCR of the birds (trial 2) reared on the other highly indigestible fibrous materials (saw dust and wood shavings) could not be unconnected with the reduction in nutrient digestibility due to materials picked from the litter by the birds Anisuzzaman \& Chowdhury, ${ }^{[1]}$, Awojobi et al., ${ }^{[2]}$.

The survivability of the birds compared favourably $(P>0.05)$ and as such the little mortality recorded in 
trial 1 could not be attributed to the effect of the litter materials, since the percentage was negligible

The carcass traits and the internal organs weights were not adversely affected by the litter materials on which they were raised.

The result of the study suggests that the three litter materials are appropriate for raising broilers since none of the litters had any adverse effect on the growth performance of the birds. However, rice husks proved to be slightly better as litter material for broiler rearing among the available litter materials in Nigeria.

\section{REFERENCES}

Anisuzzaman, M, Chowdhury, S.D. 1996. Use of four types litter for rearing broilers. British Poultry Science 37, 541-545.

Awojobi, H.A, Adekunmi, A.A., and Adebowale, O.J. 1999. Comparative Performance of Broiler chickens reared on different litter materials. Tropical Animal Production Investigations 2, $135-141$.

Babatunde, G.M. 1998. The presidential task force on alternative feed resources: Challenges and way forward Nigeria Society of Animal Production Newletter. 17(2).4

Daghir, N.J. 1995. Present status and future of the poultry industry in hot regions. In: Daghir; N.J. (ed). Poultry Production in hot Climates. Pp1-10 CABI Publishing, United Kingdom.

Demirulus, M. 2006. The effect of litter type and litter thickness on broiler carcass traits. International Journal of Poultry Science. 5 (7), 670-672.
FAO. 2000. Food and Agriculture Organizations of the United Nations. Rome Quarterly Bulletin of Statistics,

Obi, I.U. 1990. Statistical methods of detecting differences between treatment means $2^{\text {nd }}$ edn. Snaap Press, Enugu, Nigeria.

Oliveira, S.C., Cavalheiro, A.C.I., Trinidade, D.S., Lopez, J., Correa-Oliveira, S.1974. Comparison between types of litter in broiler production in Rio Grande does sul Brasil. Proceedings of the XV Ward Poultry Congress Washington U.S.A. World Poultry Association.342-344.

Popolizio, E.R., Ricci, H.R., Castellote, H.F., Pailhe, L.A. 1979 Use of different materials for poultry litter. Agronomica Zootecnica 75,14.

Poyraz, Ö., Iscan, K.A., Nazlýgül, Deliormanoglu, A. 1990. Diatomite Utilization Possibility in broiler Production. Journal Veterinary Association 47-57.

Shanmughasundaram, S., Thaigaraja, M., Venkatasubramanyan, S., Michael, R.D. 1977. Study of sanitary qualities of different poultry house litter materials and its influence on broiler Performance. Poultry Abstract 3,183.

Sharma, M.L. 1987. Comparative efficiency of litter materials for white leghorn layers including their Manureal value: Indian Journal of Animal Production and Management 3,101-102.

Smyth, J.D. 1976. Introduction to Animal parasitology. Hodder and Stoughton, London.

Steel, R.G., Torrie, J.M. 1980. Principal and Procedure of Statistics Biometrical Approach.2nd edn. McGraw-Hill Book Co.Inc. New York 638. 